\title{
A Study of Financial Distress based on MDA
}

\author{
Dr. Amalendu Bhunia \\ Reader in Commerce, Fakir Chand College \\ Diamond Harbour, South 24-Parganas \\ Pin-West Bengal, India \\ E-mail: bhunia.amalendu@gmail.com \\ Mrs. Ruchira Sarkar (Bagchi). \\ Assistant Professor, MBA Department \\ Techno India School of Management Studies, Salt Lake, Sector V, Kolkata \\ West Bengal, India \\ E-mail: ruchira2008@gmail.com
}

Received: January 25, 2011 Accepted: February 24, 2011 doi:10.5296/jmr.v3i2.574

\begin{abstract}
The present study is crucial importance to build up a model to develop the predictive abilities for company failures in a later time frame with different financial, business and operating conditions in the Indian context. A total of sixty-four private sector pharmaceutical companies were analyzed with sixteen financial ratios using multiple discriminant analysis. A strong discriminant function was constructed with seven ratios found to be significant in discriminating power and the classification results showed high predictive accuracy rates of between $86 \%$ and $96 \%$ for each of the five years prior to actual failure. This study also indicated that even with more advanced statistical tools more popularly used recently, MDA is still a very reliable and potent statistical tool.
\end{abstract}

Keywords: Financial ratios, Company failures, Failure predictions, Multiple discriminant analysis 


\section{Introduction}

Financial statement analysis is described as the process of identifying financial strengths and weaknesses of the firm by correctly launching association between the items of the balance sheet and the profit and loss account. It is usually recognized that the objective of financial statements is to offer information about the financial position, performance and changes in financial position of an enterprise that is valuable to a wide range of users in making economic decisions (Deloitte, 2007). Again, financial statement analysis is the method of accepting the risk and profitability of a firm in the course of analysis of reported financial information, by using different accounting tools and techniques for evaluating and pricing credit risk and for doing fundamental company valuation.

The financial strength of firms is of distress to numerous negotiators in society, including investors, bankers, governmental and regulatory bodies, and auditors. The credit rating of listed firms is a significant indicator, both to the stock market for investors to regulate stock portfolios, and in addition to the capital market for lenders to determine the costs of loan default and borrowing conditions for their clients. It is also the duty of government and the regulatory authorities to observe the general financial status of firms with the aim of make proper economic and industrial policy. Further, auditors require examining the going-concern position of their clients to present a precise report of their financial standing. The failure of one firm can have an effect on a number of stakeholders, including shareholders, debtors, and employees. However, if a number of firms simultaneously face financial failure, this can have a wide-ranging effect on the national economy and possibly on that of other countries (EconomicTimes.Indiatimes.com, 2010).

There are lots of causes of corporate failure which include the liquidity, solvency and profitability position. In today's economic climate overtrading can also create the risk of illiquidity and lead to corporate collapse. A prediction is a report regarding the means effects will take place in the future, frequently but not constantly based on experience. Prediction is very much associated to uncertainty (Business dictionary). Financial distress is a situation where a company cannot meet nor has intricacy paying off its financial obligations to its creditors. The chance of financial distress increases when a firm has high fixed costs, illiquid assets, or revenues that are perceptive to economic downturns. Financial distress is a term in corporate finance used to point out a circumstance when promises to creditors of a company are broken or honored with difficulty. If financial distress cannot be relieved, it can lead to bankruptcy. Financial distress is generally associated with some costs to the company; these are known as costs of financial distress (Investopedia).

Now obviously question arises? How can financial distress be predicted? This question is of curiosity not only to managers but also to external stakeholders of a company. A good number research studies on company bankruptcy and failure predictions were prepared in developed countries for example those carried out by Beaver (1966), Altman (1968) in the United States, and Ganelasingam \& Kumar, (2001) and Cybinski (2001) in Australia. Financial distress prediction happened to a significant accounting and finance research area since 1960s. Based on the cash flow outline, Beaver carried out three different univariate 
analyses_-profile analysis (comparison of mean values), dichotomous classification test and likelihood ratio analysis - so as to observe the predictive portrays and usefulness of each variable (Yu-Chiang Hu and Jake Ansell, 2006). By and large, financial distress leads business failure and downfall. Consequently, reviewing the financial trends and financial information of a business on a periodic basis, provides the analyst, important imminent with reference to the performance and position of the business and companies under review. A premature forewarning scheme replica to facilitate can predict distress and can provide signals of financial problems forward would probably be constructive in minimizing or absolute prevention of revelation to potential extensive failures for their own companies and shareholders or their clients. Based on a new trustworthy and perfect model Indian companies and beneficiaries might be benefited. The objective of the present study is to build up a collapse prediction model using multiple discriminant analysis through unusual financial ratios to attain a better prediction accuracy rates for failed and non-failed companies for each of the five years before the date of the actual company failure.

\section{Brief Review of Related Literatures}

The most primitive researches on company failures and company bankruptcies were univariate purely. The mainly recognized univariate model is most likely the 1966 study by Beaver, using other statistical techniques, for example, the multiple discriminant analysis by Altman (1968) for predicting company's future strength with confidence. Green (1978) examined the indicators of corporate health using liquidity, leverage, activity and profitability ratios to assess a company's performance and its future vision of triumph. Gibson (1982) states that financial ratios when used and interpreted properly can be effective in assessing the liquidity, profitability and debt position of a company. Chen \& Shimerda (1981) evaluated the efficacy of financial ratios to predict company's future strength and Gardiner (1995) confirmed that financial ratio analysis are the versatile tools for predicting financial distress. Andreas Charitou et al (2004) examined the incremental information content of operating cash flows in predicting financial distress and accordingly build up consistent failure prediction models for UK public industrial firms using Neural networks and logit methodology of fifty-one matched pairs of failed and non-failed UK public industrial firms over the period 1988-97. The empirical results signify that an economical model that includes three financial variables of cash flow, profitability and financial leverage variable that capitulated an overall correct classification accuracy of $83 \%$ one year prior to the failure.

Hu and Ansell (2005) constructed retail financial distress prediction models based on five key variables with good classification properties using five credit scoring techniques-Naïve Bayes, Logistic Regression, Recursive Partitioning, Artificial Neural Network, and Sequential Minimal Optimization (SMO) considering a sample of 491 healthy firms and 68 distressed retail firms for the period from 2000 to 2004. An international comparison study of three retail market models for USA, Europe and Japan illustrates that the average accuracy rates are above $86.5 \%$ and the average AUROC values are above 0.79 . More or less all market models exhibit the best discriminating ability one year prior to financial distress. The US market model executes comparatively better than European and Japanese models five years before financial distress. A composite model is erected by combining data from US, 
European and Japanese markets. All five credit-scoring methods have the most excellent classification capability in the year prior to the financial distress, with accuracy rates of above 88\% and AUROC values of above 0.84 . In addition, these techniques still continue sound five years before financial distress, as the accuracy rate is above $85 \%$ and AUROC value is above 0.72. On the other hand, it is hard to wrap up that modeling practice has the unconditional finest classification capability, in view of the fact that the composite model's performance varies consistent with diverse time scales.

\section{Methodology of the Study}

\subsection{Selection of Variables}

Chen \& Shimerda (1981) claimed that there are too many (41 ratios) financial ratios to be helpful in evaluating the financial performance and financial condition of a company. Taffler (1983) claimed there are only four out of eighty potential useful ratios in evaluating the financial performance and financial condition of a company. Koh \& Killough (1986) claimed it is not necessitated to have a huge number of ratios to predict business failures but desirable is a set of dominant ratios derived from a larger set of correlated ratios. However Hossari \& Rahman (2005) found commonly used 48 ratios in the past literatures. In the present study (Table-1), 16 ratios were selected among universally used in previous studies. These 16 ratios were selected to assess profitability, efficiency, liquidity and solvency based on their popularity as evidenced by their frequent usage in the finance and accounting literature and that the ratios have been shown to carry out fine in earlier studies.

Table 1. Selected Sixteen Ratios under the Study

\begin{tabular}{|l|l|l|l|}
\hline Sl. No. & Selected Ratios & Abbreviations & Measure \\
\hline 1 & Net Income to Total Assets & NITA & Profitability \\
2 & Retained Earnings to Total Assets & RETA & Profitability \\
3 & Earnings Before Interest and Tax & EBITTA & Profitability \\
4 & Net Income to Sales & NIS & Profitability \\
5 & Current Asset to Current Liabilities & CACL & Liquidity \\
6 & Working capital to Total Assets & WCTA & Liquidity \\
7 & Market value Equity to Total Debt & METD & Liquidity \\
8 & Cash Flow to Total Debts & CFTD & Liquidity \\
9 & Cash to Sales & CS & Liquidity \\
10 & Current Assets to Total Assets & CATA & Liquidity \\
11 & Working Capital to Sales & WCS & Liquidity \\
12 & Cash to Current Liabilities & CCL & Liquidity \\
13 & Total Debts to Total Assets & TDTA & Solvency \\
14 & Funds Flow to Total Liabilities & FFTL & Solvency \\
15 & Debtors Turnover & Debtor & Efficiency \\
16 & Sales to Total Assets & STA & Efficiency \\
\hline
\end{tabular}




\subsection{Data Collection and Sample}

Financial Statement data from the annual reports of selected failed and non-failed private sector pharmaceutical companies were taken from a ten-year period starting 1996 until the end 2005. Data of the failed companies were acquired for five years prior to failure. A total of thirty-two failed manufacturing companies are matched with thirty-two non-failed companies. Matched pair samples with the same financial ratios and different asset sizes of failed and non-failed companies are utilized. It is reasonable that a larger company with a larger asset base will have a lower probability of failure even if the ratios of the two firms are identical. The financial statements of the non-failed companies are obtained for the same fiscal years as those of the failed companies, specifically, if the failed company has a financial year ending 31 March 2006, the non-failed company would be selected with financial statements ending in the same year. The names of the failed companies that are matched with the non-failed companies are tabulated in Table 2 under:

Table 2. List of Companies used in the Analysis and Holdout Samples

\begin{tabular}{|c|c|c|c|}
\hline Sl. No. & Failed Companies & Sl. No. & Non-failed Companies \\
\hline 1 & Aarey Drugs \& Pharmaceuticals Ltd. & 1 & Amol Pharmaceuticals Pvt. Ltd. \\
\hline 2 & Alintosch Pharmaceuticals Ltd. & 2 & Amrutanjan Drugs \& Chemicals Ltd. \\
\hline 3 & Biocon Biopharmaceuticals Pvt. Ltd. & 3 & Anmol Drugs \& Pharmaceuticals Ltd. \\
\hline 4 & Concept Pharmaceuticals Ltd. & 4 & Ayurvedic Pharmaceutical Co. Ltd. \\
\hline 5 & Durga Pharmaceuticals Pvt. Ltd. & 5 & Bonanza Pharmaceuticals Ltd. \\
\hline 6 & Elegant Pharmaceuticals Ltd. & 6 & Cadila Pharmaceuticals Ltd. \\
\hline 7 & Emcure Pharmaceuticals Ltd. & 7 & Cepham Pharmaceuticals Ltd. \\
\hline 8 & Ganga Pharmaceuticals Ltd. & 8 & Dishman Pharmaceuticals Ltd. \\
\hline 9 & Hexone Pharmaceuticals Ltd. & 9 & East India Pharmaceutical Works Ltd. \\
\hline 10 & Indocare Pharmaceuticals Ltd. & 10 & Ebers Pharmaceuticals Ltd. \\
\hline 11 & Jechins Pharmaceuticals Ltd. & 11 & Glaxosmithkline Pharmaceuticals Ltd. \\
\hline 12 & M J Pharmaceuticals Ltd. & 12 & Hallmark Drugs \& Chemicals Ltd. \\
\hline 13 & Mangalam Drugs \& Organics Ltd. & 13 & Hub Pharmaceuticals Pvt. Ltd. \\
\hline 14 & Medley Pharmaceuticals Ltd. & 14 & Ifiunik Pharmaceuticals Ltd. \\
\hline 15 & Nestor Pharmaceuticals Ltd. & 15 & Intas Pharmaceuticals Ltd. \\
\hline 16 & Omega Biotech Ltd. & 16 & J K Drugs \& Pharmaceuticals Ltd. \\
\hline 17 & Paras Pharmaceuticals Ltd. & 17 & Jenburkt Pharmaceuticals Ltd. \\
\hline 18 & Parenteral Drugs (India) Ltd. & 18 & Kothari Phytochemicals \& Inds. Ltd. \\
\hline 19 & Plethico Pharmaceuticals Ltd. & 19 & Lincoln Pharmaceuticals Ltd. \\
\hline 20 & Relish Pharmaceuticals Ltd. & 20 & Macleods Pharmaceuticals Ltd. \\
\hline 21 & Sarala Pharmaceuticals Ltd. & 21 & Maneesh Pharmaceuticals Ltd. \\
\hline 22 & Srini Pharmaceuticals Ltd. & 22 & Mesco Pharmaceuticals Ltd. \\
\hline 23 & Standard Pharmaceuticals Ltd. & 23 & Novus Pharmaceuticals Ltd. \\
\hline 24 & Suyog Pharmaceuticals Pvt. Ltd. & 24 & Om Pharmaceuticals Ltd. \\
\hline 25 & Sharvani Pharmaceuticals Ltd. & 25 & Paam Drugs \& Pharmaceuticals Ltd. \\
\hline 26 & Troikaa Pharmaceuticals Ltd. & 26 & Poonam Pharmaceuticals Ltd. \\
\hline 27 & Unicorn Pharmaceuticals (India) Ltd. & 27 & Ranbaxy Drugs Ltd. \\
\hline
\end{tabular}




\begin{tabular}{|l|l|l|l|}
\hline 28 & Venmax Drugs \& Pharmaceuticals Ltd. & 28 & Reliance Pharmaceuticals Pvt. Ltd. \\
29 & Vista Pharmaceuticals Ltd. & 29 & Sanjeevanee Pharmaceuticals Ltd. \\
30 & Wallace Pharmaceuticals Ltd. & 30 & Sri Krishna Pharmaceuticals Ltd. \\
31 & Welcure Drugs \& Pharmaceuticals Ltd. & 31 & Torrent Pharmaceuticals Ltd. \\
32 & Zental Drugs Ltd. & 32 & Universal Pharmaceuticals Ltd. \\
\hline
\end{tabular}

\subsection{Multiple Discriminant Analysis}

Multiple discriminant analysis is a statistical technique used to reduce the differences between variables in order to classify them (failing and non-failing companies under the study) into a set number of broad groups. Hair, Tatham, Anderson, \& Black (2006) claimed that multivariate analysis concurrently examine several dimensions on every character or thing under study. This is prepared by the statistical judgment rule of maximizing the between group variance relative to the within-group variance and is articulated as the ratio of the between group to the within-group variance. A linear combination of the variables utilized is formed into an equation:

$$
\mathrm{Z}=\mathrm{a}+\mathrm{b}_{1} \mathrm{X}_{1}+\mathrm{b}_{2} \mathrm{X}_{2}+\mathrm{b}_{3} \mathrm{X}_{3}+\ldots \ldots \ldots \ldots \ldots+\mathrm{bnXn}
$$

Where $\mathrm{Z}=$ the score,

$\mathrm{a}=$ the constant

$\mathrm{b}=$ the discriminant coefficient

$\mathrm{X}=$ the independent variables

Edward Altman is well-known for using multiple discriminant analysis in creating the Altman-Z score. But he did not release how his variables were selected. Nonetheless, his Z-Score has been widely used for predicting financial distress. The majority of the past researches, as, Adiana et al. (2008), Zulkarnain et al. (2001) and Menard (1995) have employed the stepwise method, however, in the present study enter method has been used to find out the finest combination of variables with the intention of presenting the highest prediction accuracy rates over the study period taking into consideration to facilitate each model and the function created and accepted must be strong as indicated by the size of the eigen value. The larger the eigen value the better the discriminating power of the function. The Wilk's Lambda value and the Chi-Square value are in addition evaluated to find out discriminating power. The Wilk's Lambda has been used to evaluate the differences between groups and the homogeneity within groups. A low Wilk's Lambda and a large Chi-Square with a significant p-value designates good discriminating power of the discriminant function.

To decrease the huge number of selected financial ratios, several MDA runs on the SPSS are executed with diverse combination of ratios. For each function created, the model fit will be assessed on how sturdy is the function, how fine it discriminates and ensuring the classification matrices for predictive accuracy not just for the fail companies and non-fail companies also. The cross validation of U-method has also been assessed to ensure that they are close to the results from the analysis sample and for the validity of a function by removing items at a time and classifying them into the discriminant groups using a function 
developed from the remaining companies in the analysis sample. The function accepted must be able to have reasonably high classification capabilities not just for certain years but for all five years. Since MDA is a multivariate technique, the assumptions essential multiple regression analysis are applicable. According to Back, Laitinen, Sere \& Wezel (1996) where the variables in the group pursue a multivariate normal distribution and when each group covariance matrices are equal, it will violate the normality as well as the equal group variance conditions; the MDA technique had not exposed any refuse in its classification ability.

\section{Findings of the Study}

From the numerous MDA runs, one discriminant model was selected derived from the log transformed values of each of the selected ratios. The discriminant function has a $50 \%$ probability of group membership, specifically, failed and non-failed.

Seven financial ratios were selected among the 16 ratios, namely FFTL, CFTD, TDTA, WCTA, RETA, EBIT and NIS. Three of the ratios (TDTA, WCTA and RETA) were incorporated by Altman (1968) as among the five that was used in the well-known Z-Score MDA model. Of these seven financial ratios, three of the ratios (46\%) measure liquidity, another three ratios (38\%) measure profitability and one ratio (16\%) measures solvency. The collapse of these seven ratios in terms of what they measure and how they compare to the 10 most popular financial ratios found to be helpful, as supported in, Hossari \& Rahman (2005).

Table 3. Comparisons of Financial Ratios Selected and what they Measure

\begin{tabular}{|l|l|l|l|}
\hline Present Study & Percentage & Past Study & Percentage \\
\hline Liquidity & 46 & Liquidity & 40 \\
Profitability & 38 & Profitability & 40 \\
Solvency & 16 & Solvency & 20 \\
\hline
\end{tabular}

Table-3 illustrates that liquidity and profitability ratios are most significant in predicting a company's financial health. For the analysis sample, the average classification accuracy rates for five years prior to actual failure are $86 \%$ for both the failed and non-failed companies in the analysis sample and $78.2 \%$ on the whole for both the failed and non-failed companies when internally validated seeing that exposed in Table 4.

For the holdout sample, the resultant outcomes are $86 \%$ for both the failed and non-failed companies and $86.6 \%$ overall for both the failed and non-failed companies when internally validated as shown in Table 5.

Table 4. Results - Analysis Sample

\begin{tabular}{|l|l|l|l|l|l|l|}
\hline $\begin{array}{l}\text { Correct Classification } \\
\text { (\%) }\end{array}$ & $\begin{array}{l}\text { Year 1 } \\
\text { (\%) }\end{array}$ & $\begin{array}{l}\text { Year 2 } \\
\text { (\%) }\end{array}$ & $\begin{array}{l}\text { Year 3 } \\
\text { (\%) }\end{array}$ & $\begin{array}{l}\text { Year 4 } \\
\text { (\%) }\end{array}$ & $\begin{array}{l}\text { Year 5 } \\
\mathbf{( \% )}\end{array}$ & $\begin{array}{l}\text { Average 5 Years } \\
\text { (\%) }\end{array}$ \\
\hline Fail & 96 & 84 & 86 & 90 & 76 & 72 \\
Non-Fail & 82 & 96 & 82 & 78 & 96 & 84.8 \\
Average & 86 & 90 & 84 & 84 & 86 & 86 \\
Cross-validation (Av) & 88 & 82 & 72 & 71 & 78 & 78.2 \\
\hline
\end{tabular}


Table 5. Results - Holdout Sample

\begin{tabular}{|l|l|l|l|l|l|l|}
\hline $\begin{array}{l}\text { Correct Classification } \\
\text { (\%) }\end{array}$ & $\begin{array}{l}\text { Year 1 } \\
\text { (\%) }\end{array}$ & $\begin{array}{l}\text { Year 2 } \\
\mathbf{( \% )}\end{array}$ & $\begin{array}{l}\text { Year 3 } \\
\mathbf{( \% )}\end{array}$ & $\begin{array}{l}\text { Year 4 } \\
\mathbf{( \% )}\end{array}$ & $\begin{array}{l}\text { Year 5 } \\
\mathbf{( \% )}\end{array}$ & $\begin{array}{l}\text { Average 5 Years } \\
\mathbf{( \% )}\end{array}$ \\
\hline Fail & 80 & 90 & 86 & 86 & 90 & 86.4 \\
Non-Fail & 90 & 86 & 84 & 80 & 86 & 84.8 \\
Average & 85 & 88 & 85 & 83 & 96 & 86.2 \\
Cross-validation (Av) & 81 & 80 & 72 & 68 & 82 & 76.6 \\
\hline
\end{tabular}

It is important to observe that high accuracy rates are attained for the fourth and fifth years prior to failure of between $90 \%$ and $76 \%$ for both the failed and non-failed companies in the analysis sample (Table 4) and between $86 \%$ and $96 \%$ for the holdout sample (Table 5). Not many past studies manage to achieve these high rates of success the further away the time period is from the actual failure.

The potency of the functions and discriminating abilities were all assessed by checking the eigenvalues, Wilk's Lambda and Chi-Square and its significance level. The information on the discriminant function was shown in Table 6 and Table 7 under. The results for each of the five years illustrated that a reasonably strong function was developed with reasonably large Eigenvalues, low Wilk's Lambda and high Chi-Square values at significance levels. It also point out that the function discriminate well. These results are valid for both the analysis and the holdout samples. The only exception is for Year 4 in the analysis sample where the Eigenvalue is less than 1 and the Chi-Square value is lower with a significant value of $>0.05$. This is also reflected in the poorer classification rate of only $79 \%$ on an average (Table 4) for the non-failed companies for that year.

Table 6. Model Function Information - Analysis Sample

\begin{tabular}{|l|l|l|l|l|l|l|}
\hline Statistics & Year 1 & Year 2 & Year 3 & Year 4 & Year 5 & Average \\
\hline Eigen Values & 1.08 & 1.99 & 1.12 & 0.67 & 1.38 & 1.248 \\
Wilks Lambda & 0.30 & 0.25 & 0.50 & 0.54 & 0.40 & 0.398 \\
Chi-Square & 26.77 & 28.89 & 18.24 & 13.86 & 22.69 & 22.09 \\
Significance & 0.00 & 0.00 & 0.01 & 0.034 & 0.000 & 0.0088 \\
Box's M (p-value) & 0.00 & 0.00 & 0.00 & 0.00 & 0.000 & 0.00 \\
\hline
\end{tabular}

Table 7. Function Information - Holdout Sample

\begin{tabular}{|l|l|l|l|l|l|l|}
\hline Statistics & Year 1 & Year 2 & Year 3 & Year 4 & Year 5 & Average \\
\hline Eigen Values & 1.23 & 2.38 & 1.01 & 0.97 & 1.89 & 1.496 \\
Wilks Lambda & 0.35 & 0.38 & 0.53 & 0.46 & 0.40 & 0.424 \\
Chi-Square & 24.91 & 27.08 & 17.86 & 18.64 & 26.84 & 23.066 \\
Significance & 0.00 & 0.01 & 0.002 & 0.038 & 0.000 & 0.01 \\
Box's M (p-value) & 0.00 & 0.00 & 0.00 & 0.00 & 0.000 & 0.00 \\
\hline
\end{tabular}

The Box's M Test of Equality of Covariance Matrices showed a p-value of $<0.05$ for the 
MDA function constructed for each of the years and for both the analysis and the holdout sample as shown in Table 4 and Table 5 above. This is an indication of equality of variance-covariance matrices and high correct classifications that treated as a violation of this assumption in case of classification capability. The empirical findings illustrates that a strong statistical model can be created which is able to predict company failures with very high correct classifications for each of the five years before the actual failure.

\section{Conclusion}

The present study examines the degree to predict company failures using multiple discriminant analysis in the Indian context based on a total of 64 companies with 16 financial ratios. A strong discriminant function was constructed with selected ratios found to be significant in its discriminating power and the classification results illustrated high predictive accuracy rates. Particularly, the MDA model constructed has good predictive abilities with accuracy rates of $86 \%$ on average for the analysis sample and $86.2 \%$ on average for the hold-out sample for the study period prior to actual failure. The empirical results recommend that there is a convincing association between financial ratios and company health and business failures and at the same time financial ratios do have predictive power concerning whether a company will be successful or fail. The empirical results also disclose that selected liquidity and profitability ratios are helpful in predicting a company's success or failure.

\section{References}

Adiana N. H. A, Halim A., Ahmad H. and Rohani M. R. (2008). Predicting Corporate Failure of Malaysia's Listed Companies: Comparing Multiple Discriminant Analysis, Logistic Regression and the Hazard Model, International Research Journal of Finance and Economics Iss 5, pp $202-217$.

Altman, E. I. (1968). Financial Ratios, Discriminant Analysis and the Prediction of Corporate Bankruptcy, Journal of Finance, 23(4), pp. 589-609.

Andreas Charitou, Evi Neophytou And Chris Charalambous (2004). Predicting Corporate Failure: Empirical Evidence for the UK, European Accounting Review, Vol. 13, No. 3, 465-497.

Back, B, Laitinen, T, Sere, K and Wezel, M. (1996). Choosing bankruptcy Predictors Using Discriminant Analysis, Logit Analysis, and Genetic Algorithms, Turku Centre for Computer Science, Technical Report No 40, September. pp. 1-1.

Balcaen, S. \& Ooghe, H., (2006). 35 Years of Studies on Business failures. An overview of the classic statistical methodologies and their related problems, The British Accounting review, Vol 38(1), pp. 63-93.

Beaver, W. H. (1966). Financial Ratios as Predictors of Failure, Journal of Accounting Research, Vol 4. pp. 71-111

Bhunia, A. (2008). A Discriminant Analysis and Prediction of Liquidity-Profitability, V.U.Journal of Commerce, vol. 13, March 2008, pp.100-106. 
Chen, K. H. \& Shimerda T. A. (1981). An Empirical Analysis of Useful Financial Ratios, Financial Management, Spring, pp51-60

Cybinski, P. J. (2000). The Path to Failure: Where are Bankruptcy Studies Now, Journal of Business and Management, 7(1), pp.11-3.

Deloitte (2007). The Framework for the Preparation and Presentation of Financial Statements, International Accounting Standards Board, Accessed 24 June 2007, http://www.svtuition.org/2011/08/corporate-financial-reporting.html

EconomicTimes.Indiatimes.com (2010).

file://N:/Prediction/CORPORATE\%20FAILURE\%20\%20DEFINITIONS,\%20METHODS, \%20AND\%20FAILURE\%20PREDICTION\%20MODELS\%20\%28Finance\%29.htm

Ganesalingam, S. \& Kumar, K., (2001). Detection of Financial distress via Multivriate Statistical Analysis, Managerial Finance, Vol 27(4), pp 45-55

Gardiner, M. A., (1995). Financial Ratios Definitions Reviewed, Management Accounting, September, Vol.73(8), pp. 32.

Gepp, A. \& Kumar, K. (2008). The Role of Survival Analysis in Financial Distress Predictions, International Research Journal of Finance and Economics, Issue 16, pp13-3.

Gentry, C. Newbold, P. \& Whitford D., (1990). Profiles of cash flow components, Financial Analysis Journal, Vol. 46(4), 41-48.

Gibson, C. (1982). Financial Ratios in Annual Reports, The CPA Journal September, pp. 18-29

Green, D. (1978). To Predict Failure, Management Accounting July pp.39-45

Hair, J. F., Tatham, R. L., Anderson, R. E. \& Black, W., (2006). Multivariate data analysis, Prentice Hall, New Jersey, USA..

Holmen, J. S. (1988). Using financial ratios to predict bankruptcy: An evaluation, Akron Business and Economic Review, Vol. 19(1), 52-63.

Hossari, G \& Rahman, S. (2005). A Comprehensive Formal Ranking of the Popularity of Financial Ratios in Multivariate Modeling of Corporate Collapse, Journal of American Academy of Business, Cambridge, Mar. pp. 321-327

Ganesalingam, S. \& Kumar, K. (2001). Detection of Financial distress via Multivriate Statistical Analysis, Managerial Finance, Vol 27(4), pp 45-55.

Li, H. \& Sun, J. (2010). Business failure prediction using hybrid case-based reasoning HCBR, Computers \& Operations Research January 2010. pp. 137-151.

Letza, S. R., Kalupa, L. and Kowalski, T. (2003). Predicting corporate failure: How useful are multi-discriminant analysis models? The Poznan University of Economics Review, Vol. 3/ 2, pp. 5-11 


\section{Macrothink}

Journal of Management Research ISSN 1941-899X 2011, Vol. 3, No. 2: E8

Moyer, R. C. (1977). Forecasting Financial Failure: A Re-Examination, Financial Management, Spring, Vol. 6(1) pp. 11-17

Ohlson, J. A. (1980). Financial Ratios and the Probabilitstic Prediction of Bankruptcy, Journal of Accounting Research, Spring, pp. 109-131.

Pramodh, C. \& Ravi, V. (2007). Modified Great Deluge Algorithm based Auto Associative Neural Network for Bankruptcy Prediction in Banks, International Journal of Computational Intelligence Research. Vol.3(4). pp. 363-370.

Taffler R. J. (1983). The Assessment of Company solvency and Performance Using a Statistical Model, Accounting and Business Research, Autumn, pp.295-307.

Yu-Chiang Hu and Jake Ansell (2006). Developing Financial Distress Prediction Models, Developing Financial Distress Prediction Models, 1-22.

Zulkarnain, M.S., Mohamad Ali, A.H., Annuar, M.N. and Zainal Abidin, M. (2001). Forecasting corporate failure in Malaysian industrial sector firms”, Asian Academy of Management Journal, 6(1), pp. 15-30. 